\title{
Archaeological and Ethnographic Survey in the Paikuli Area (Iraqi Kurdistan)
}

\author{
Julian Bogdani \\ Università di Bologna \\ email: julian.bogdani@unibo.it

\section{Luca Colliva} \\ Sapienza Università di Roma \\ email: luca.colliva@gmail.com

\section{Camilla Insom} \\ Sapienza Università di Roma \\ email: camillainsom@gmail.com
}

\begin{abstract}
The Italian Archaeological Mission in Iraqi Kurdistan (MAIKI) of the Sapienza University of Rome aims to study the archaeological, historical, linguistic and cultural development of the Kurdish region through a wide historical period. MAIKI started by focusing on the archaeological and philological analysis of the Sasanian site of Paikuli. In recent years, however, investigation has been expanded to include an accurate survey of the area

for the activities of the ethnological research that joined the Mission in 2013. The area suffered very much during Saddam Hussein's Al-Anfal campaign when all of the people were forced to leave. The ethnological study will help to reveal the impact that these recent traumatic events have had on the preservation of the cultural heritage whilst supplying rich documentation for further investigation, including on relationship between man and territory, local economy, migration policies and religious practices.
\end{abstract} between the Dyala and Basara rivers, around the main road that connects the city of Chamchamal to Darbandikhan, in order to implement a complete and updated archaeological map of the entire territory. The continuing work includes a preparatory study of the few bibliographical records available and an overall analysis of the accessible, current and historical satellite imagery in order to obtain a reliable context for the results of archaeological field surveys. During the field campaigns, which are currently suspended because of the political instability and war in the region, archaeological material was collected in all the visited sites and a detailed morphological and archaeometric study was set up. A complete map of the currently inhabited villages of the area has been compiled because up-to-date base cartography of the area did not exist; this new map has proved to be useful not only for locating archaeological records but also
Keywords: Kurdistan, Landscape Archaeology, Near Eastern Archaeology, Archaeological Survey

\section{Introduction}

The Italian Archaeological Mission in Iraqi Kurdis$\tan$ (MAIKI) of Sapienza University of Rome was established in 2011 to continue the work of the joint Italian research team of Sapienza and the Istituto Italiano per l'Africa e l'Oriente (IsIAO) that has been active in the region since 2006 (Cereti \& Giunta, 2012). All activities are made possible thanks to the contribution of the Italian Ministry of Foreign Affairs and the Italian Development Cooperation and the continuous support of the Italian Embassy in Baghdad and the Italian Consular Office in Erbil. MAIKI currently conducts research in all the prov- 


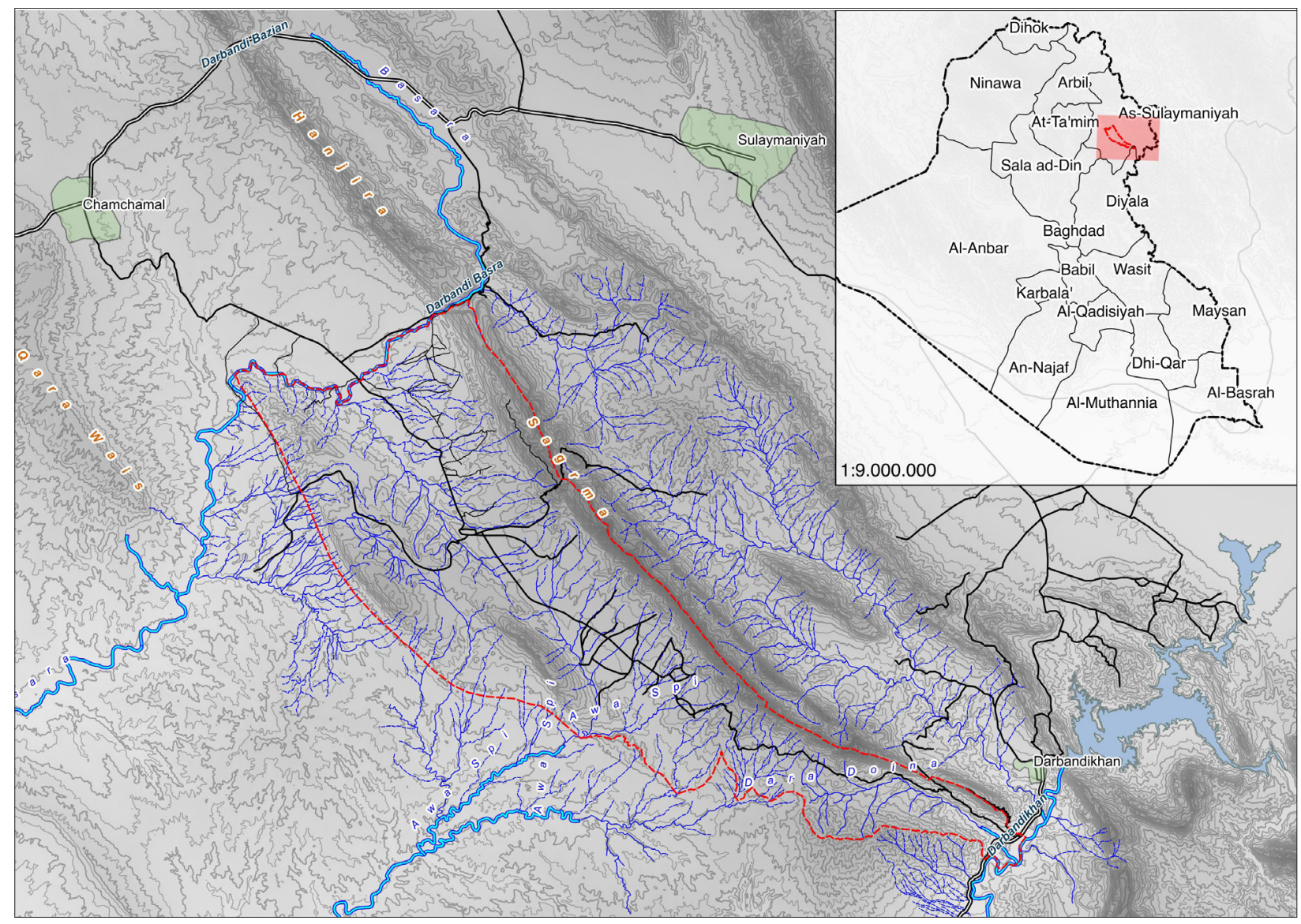

Fig. 1. General map of the study area (Italian Archaeological Mission in Iraqi Kurdistan.

inces of the autonomous region of Iraqi Kurdistan (KRG), Erbil, Sulaimaniyah and Duhok. It operates in close collaboration with local institutions responsible for the preservation, management and enhancement of cultural heritage, such as the High Commission for the Erbil Citadel Revitalisation (HCECR) and the archaeological museums of the three provinces (Cereti et al, 2014). Whilst fieldwork commenced in 2012 it was stopped in 2014 by the region's acute and continuing political instability and war; in 2015 field activities were limited to data analysis in Sulaimaniyah.

Among the Mission's activities, the archaeological study of a selection of geognostic surveys and geo-archaeological stratigraphic research of the
Erbil Citadel, carried out jointly with the HCECR, has proven to be particularly noteworthy. The fruitful collaboration is continuing with the study of the archaeological finds from excavations carried out by the HCECR. This article, however, will focus exclusively on the historical, philological, archaeological and ethnographic research conducted in the area surrounding the archaeological site of Paikuli, in the Sulaimaniyah province. The Sasanian site of Paikuli is located in the southernmost portion of the Sagrma range $(1,878 \mathrm{~m})$ part of the western Zagros Mountains, about $50 \mathrm{~km}$ south of Sulaimaniyah and $7 \mathrm{~km}$ west of Darbandikhan (fig. 1). During the Sasanian period the area represented the north-eastern border of the Asōrestān province, whose capital was Ctesiphon (Cereti, Terribili \& Tilia, in press).

The site of Paikuli includes a memorial building (fig. 2) bearing a significant bilingual inscription in Middle Persian and Parthian celebrating events that led to the accession to the throne of 


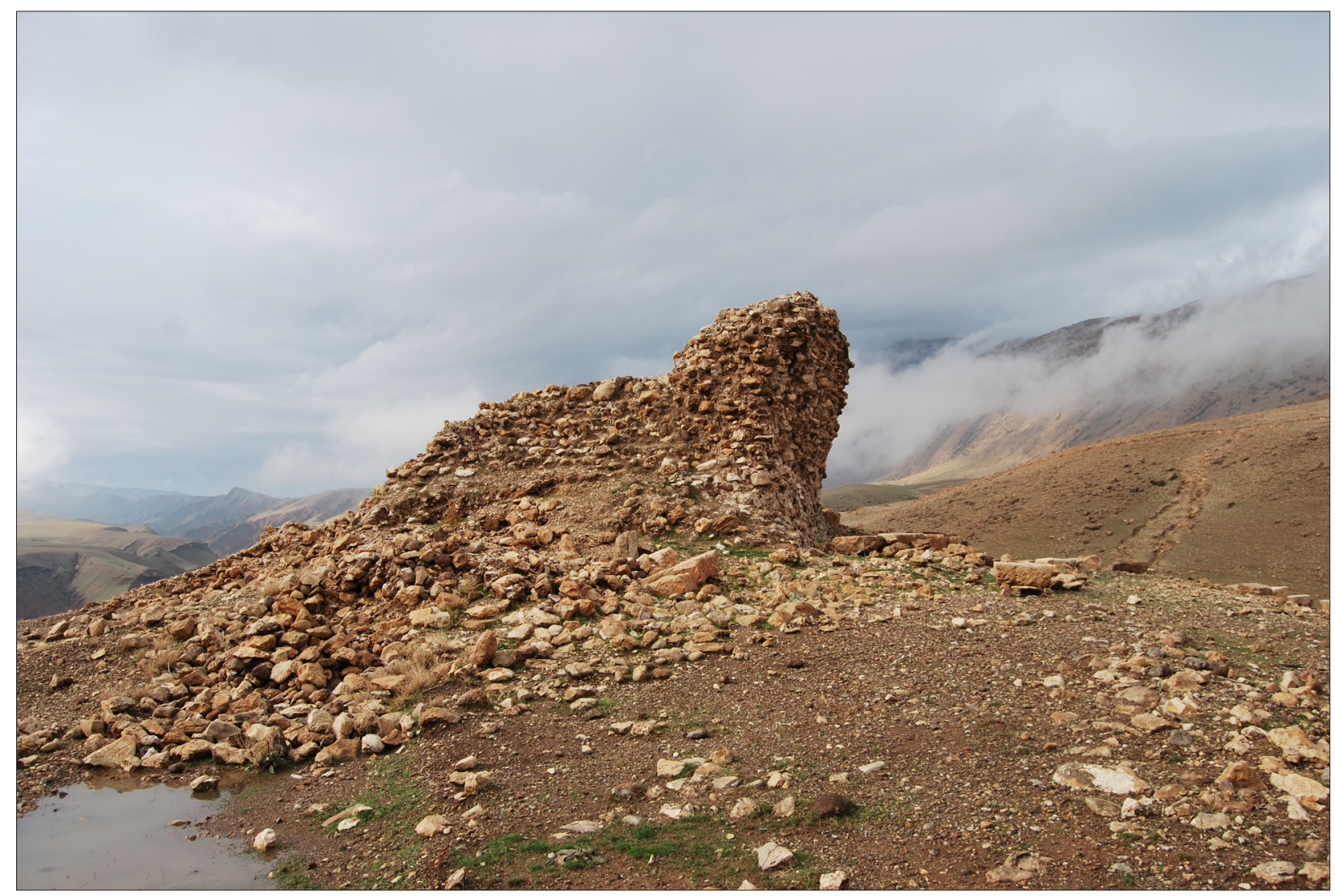

Fig, 2. Archaeological remains of the Paikuli monument (Italian Archaeological Mission in Iraqi Kurdistan).

the Sasanian sovereign Narseh (AD 293-302). It was erected in the exact place where the nobles of the empire waited and greeted the arrival of the king after his victory over his rival Wahrām III (Cereti \& Terribili, 2014). This detail highlights the importance of Paikuli area as crucial border point on the road that linked the Mesopotamian plain and the Iranian plateau (Cereti, Terribili \& Tilia, in press). The German archaeologist Ernst Herzfeld, who first studied the monument, hypothesised a tower-shaped structure, assuming a comparison with the Achaemenid monument known as the KaDba-i Zardušt at Naqš-e Rostam (Fars, Iran) which presents a long trilingual inscription in Greek, Parthian and Middle-Persian, engraved by Sabuhr I, father of Narseh (Cereti \& Terribili, 2012; Herzfeld, 1924; Huyse, 1999). The exact structure of the monument and its possible models remain, however, uncertain. While the search for new inscribed fragments and a new recording and analysis of the available blocks is still on-going, in 2012 MAIKI launched a new survey project on a large part of the surrounding territory. As well as identifying and documenting all the archaeological traces still visible, the surveys will contextualise the monument in the broadest diachronic perspective possible.

L.C.

\section{The survey area}

The area under investigation by archaeological survey and surface collection covers approximately $850 \mathrm{~km}^{2}$ between the city of Chamchamal and Darbandikhan. On the north and south the survey area is defined by the Dyala and Basara rivers, to the west by the low (circa $1375 \mathrm{~m}$ ) ridge that falls almost vertically along foothills of the Ashdagh mountain and on the east by the Sagrma mountain range (circa 1,878 m), (fig. 1). 


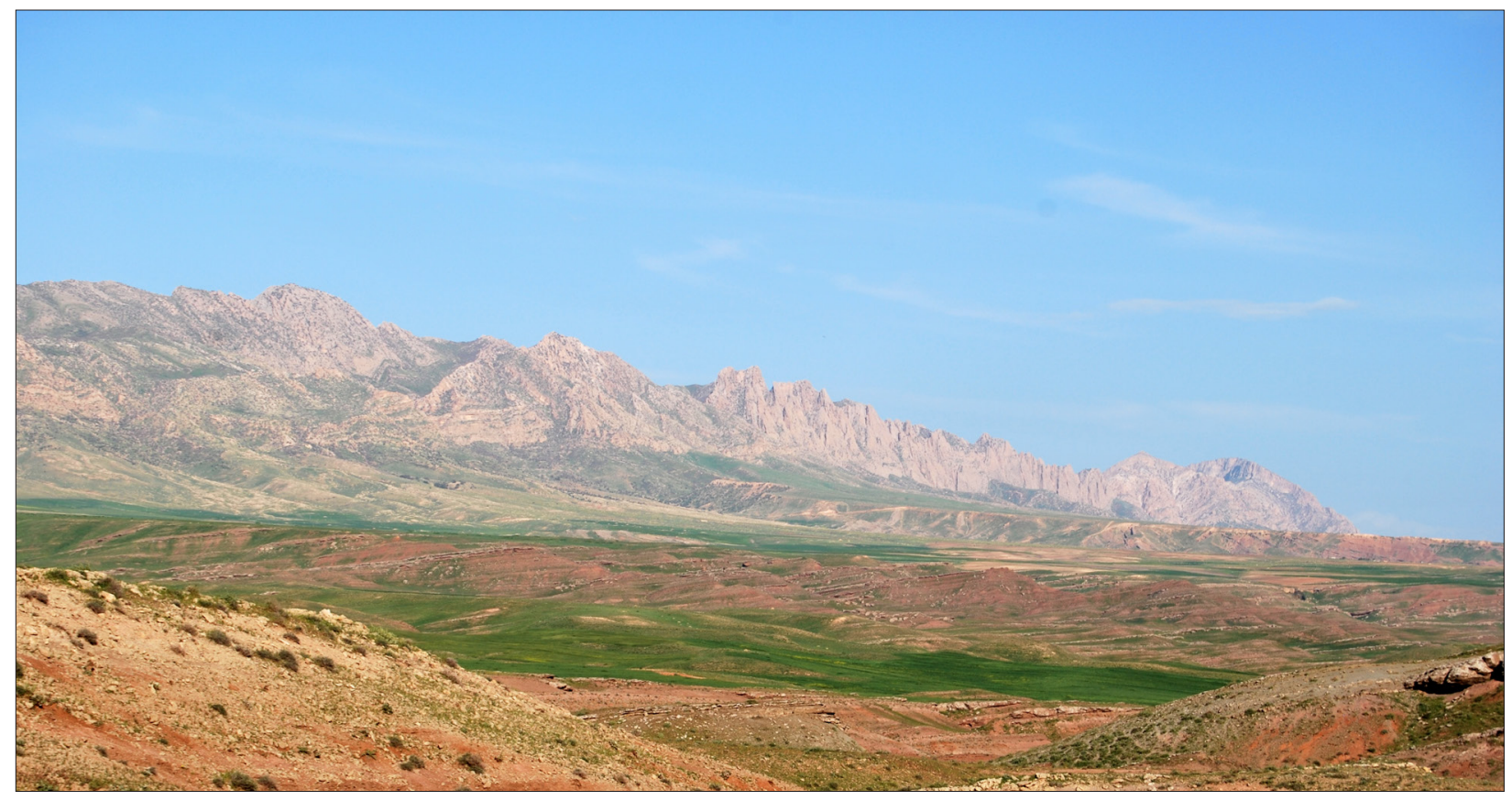

Fig. 3. View of the southern part of the Sagrma (Qara Dagh) mountains, near the Paikuli gorge (Italian Archaeological Mission in Iraqi Kurdistan).

The Sagrma mountains form the last important ridge of the Zagros chain toward the Mesopotamian plain, constituting a barrier and a natural border which can be easily crossed only through a few mountain passes. To the north, the most important pass is Darbandi Bazian, connecting the cities of Kirkuk and Sulaymaniyah; here stands a fortified palace of late-Sasanian or early-Islamic age, used as a church at an unidentified date (Cereti, Terribili \& Tilia, in press; for the geological aspects see Sissakian, 2010). Further south, on the northern edge of the survey area, is the gorge of Darbandi Basara, crossed in the Ottoman period by a caravan track linking Baghdad to Sulaymaniyah and today by a secondary road following the course of the river and linking Sulaimaniyah to Chamchamal. The third important pass, the southernmost, where stood the Paikuli monument and another Sasanian palace, contains the Dyala river as it flows south into the Tigris south of Baghdad (Cereti, Terribili \& Tilia, in press). A fourth pass, less useable when compared to those described above, is not far from the village of Krpchna, important centre of the Kasnazaniyya branch of the Qadiriyya Sufi order. This pass is crossed by a difficult road, but has lately become an increasingly important east-west route, surpassing the northernmost road of the Basara pass, probably influenced by the growth in status of the modern village of Sangaw, the urban hub of the survey area, at the crossing of major north-south and east-west routes.

The area presents a very discontinuous relief, mostly hilly, with few peaks above 1,000 m.a.s.l. affected by pronounced erosion phenomena partly due to the almost total lack of vegetation (fig. 3). Until the first half of the twentieth century, however, the Sagrma range and perhaps even the Ashdagh mountain, were covered with trees and vegetation, while today it can be said that the process of deforestation is complete (Guest, 1966: 88-89; Stansfield, 2003: 75). The area, especially in its western part, is also affected by the karst phenomena, creating sinkholes, tunnels and caves. With regard to hydrology, the area is part of three distinct fluvial basins. First, the northern part is crossed by left bank tributaries of the Basra, mostly characterised by a torrential regime, 


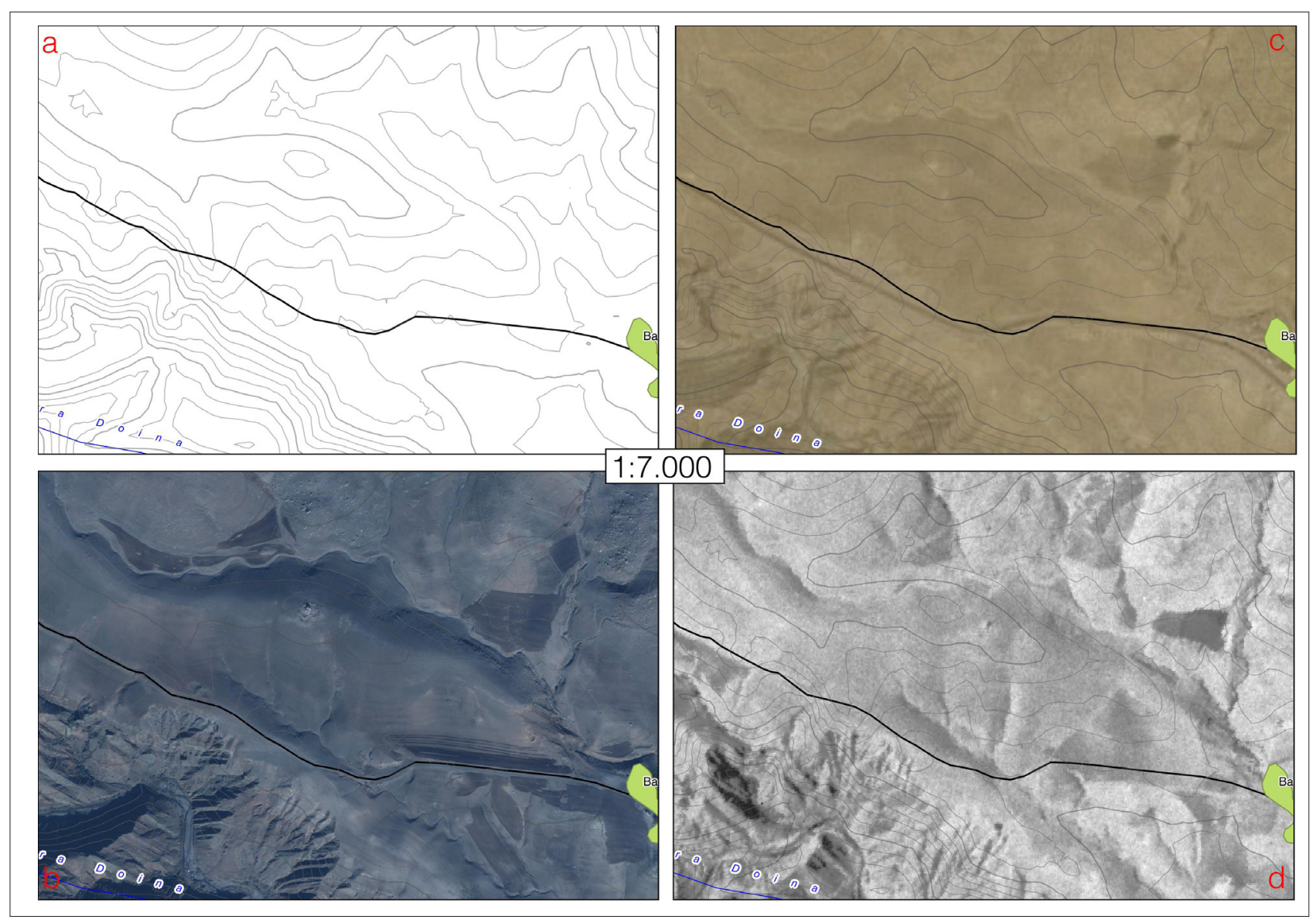

Fig. 4. Different imagery resources for the same area (Paikuli, MSP-S100): a) contour lines extracted from Quickbird stereocopies; b) Quickbird high-resolution satellite image; c) Google Earth (low-resolution) image; d) CORONA image (Italian Archaeological Mission in Iraqi Kurdistan).

with the only exception a branch that crosses our area in a south-north sense. Second, the Ashdagh mountain is the watershed of the Awa Spi, a left bank tributary of the Tigris. Third, the Dara Doina, a right tributary of the Dyala, crosses the southern area. Geologically, this is a highly unstable area, located at the exact intersection between the (still very active) Arabian and the Eurasian (or Iranic) plates (Sissakian, 2010). Surely, though, considering the advanced deforestation of the entire area, the main factor of change in the short term is the erosive activity of wind and watercourses, especially the smaller ones that have a torrential regime.

Lastly, regarding settlements, the investigated area is currently scattered with villages, often small or very small, with the sole exception of Sangaw that seems to be experiencing a growth of population. The houses are mostly constructed with the traditional building technique of mud brick and covered with straw and mud, and are usually flanked by enclosures for the animals, with cemeteries located always outside the villages, sometimes at significant distances, usually over small bumps or other morphological rises. It can be asserted that until today the impact of man on nature and territory has rarely been destructive or invasive.

J.B. 


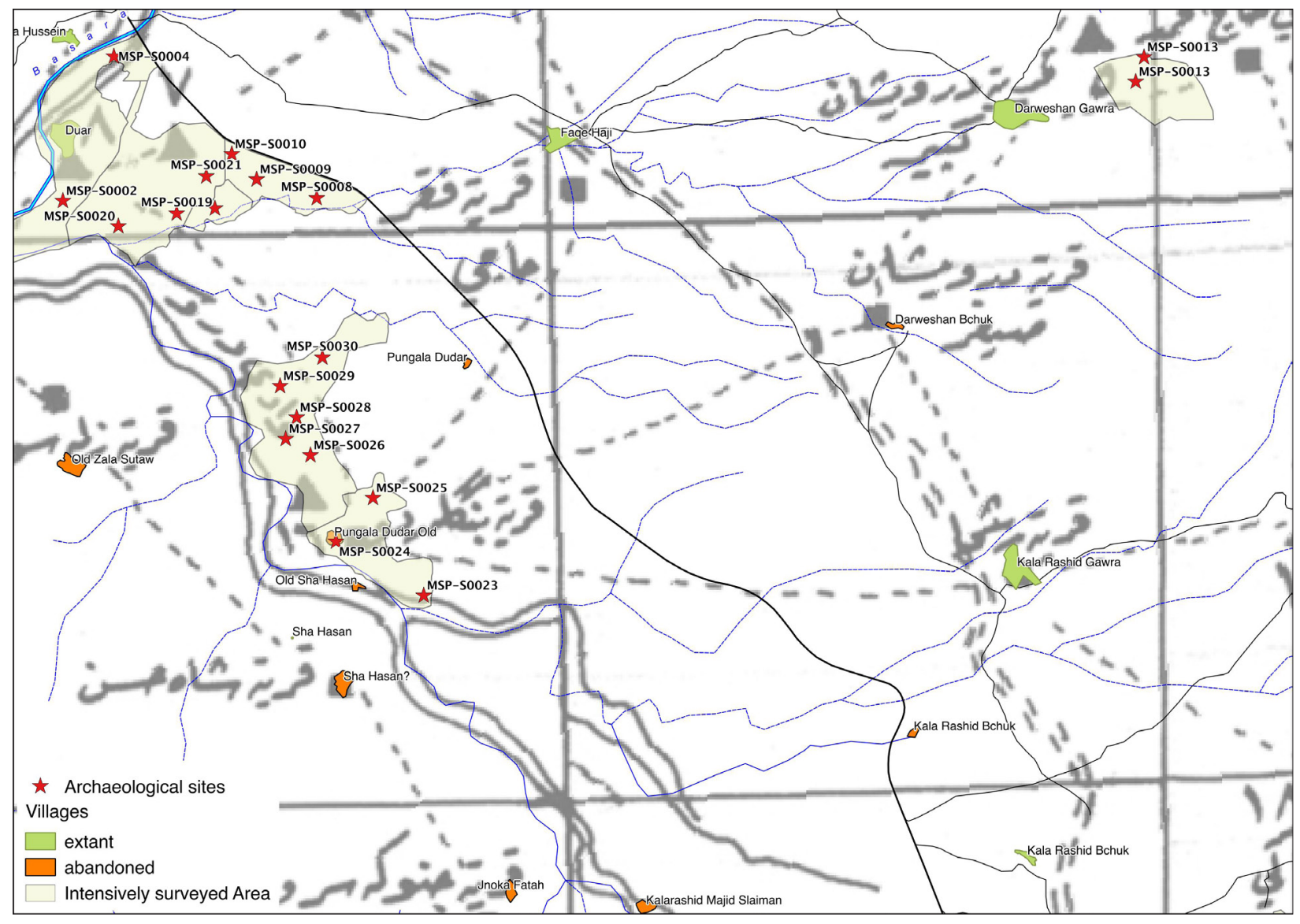

Fig. 5. Detailed view of the northern part of the survey area (Italian Archaeological Mission in Iraqi Kurdistan).

\section{Methodology - Satellite Images, Field Survey, Mapping and Artefact Collection}

The first stage of the research included the identification of archaeological sites and remains. The only available publication is an atlas edited by the General Directorate of Antiquities in Iraq, published in the second half of the last century (Atlas of the archaeological sites, 1975: 99), which lists about 44 archaeological sites, indicating for each one the name and a very rough location. It was necessary therefore to begin with satellite imagery. In many respects, and as expected, the two accessible sources that gave the best results are without doubt the declassified CORONA images (Ur, 2003; 2013) and the free Google satellite imagery. The best CORONA images available for the investigated area are the $\mathrm{KH}-4 \mathrm{~A}$ series, acquired between 1963 and 1969, with a best ground resolution of 9 feet $(2.75$ m). Nevertheless these images did not prove to be decisive for the recognition of potential archaeological sites, due to several factors. Their ground resolution is not adequate to identify smaller sites or sites lacking important above-ground structures, which represent the majority of archaeological sites of our area (the site of Paikui, for example, is hardly visible in this kind of imageryl. Furthermore, the landscape of the area, hilly, irregular and highly exposed to erosion, does not allow an easy identification of "tells", the artificial hills formed by the accumulation over long time in continuously inhabited sites of debris and building materials. The geomorphological aspect constitutes an important obstacle in the use of these images, especially in comparison with other contexts, such as the Mesopotamian plain, where they have proven to be a valuable tool. 
The CORONA imagery, however, can be successfully used to track the most recent changes in the settlement pattern of our area.

Free Google satellite images provide a high-resolution coverage for most of the area with the exception of the eastern mountainous part. We were thus able to map a large number of potential archaeological sites whose position, typology and chronology are being verified by the field-walk campaigns (fig. 4). At first, only the major anomalies, which had better chances to bear archaeological interests, were mapped; this data and the bibliographical record were the starting point of the first ground-truth survey operations. Later, a much more detailed analysis of the satellite imagery was planned, aimed at recording any anthropic intervention, of any date, in the landscape. This was partly due to the commencement of the ethnographic research on the area (2013).

Furthermore, the first results of the field activities showed a richer than expected archaeological background and many sites initially interpreted as recently abandoned presented, in fact, earlier materials. This accurate remote sense survey is still on-going and will be completed in the next months.

Remote sensing and field-walking offer a partial vision of the general archaeological frame for a given area as they can document only what is visible at a particular moment and place; they are also unable to seize the complex diachronic history of a site or area. Notwithstanding, especially given the logistical difficulties, limited resources and the high political instability of the region preventing a program of intensive survey for the entire area, they are the most accurate means to investigate larger parts of a territory. We have also focussed on the bigger sites, while intensive field survey was carried out in smaller sample areas to try to fill some of the archaeologically-blank areas (fig. 5) (Cereti et al, 2014). All data so far collected remain largely incomplete, but we hope, and our Kurdish partners share our confidence, that we will soon be able to resume our activities.

The lack of an official base cartography created some difficulties to the archaeological and ethno- graphic campaigns; hence in 2014 a new map of all the villages of the area was compiled, including the exact positioning of each village, its name or names, a brief description and a photographic documentation. The map includes both inhabited villages, fundamental for planning the ethnographic research and the complete list of the abandoned ones. The latter have proved to be useful to interpret some major anomalies recorded by the remote sensing analysis. Besides, the collected toponyms offer valuable information on population and the history of their settlements; while this is a topic that deserves further study some recurring cases can be mentioned. Many villages are known to have more than one name and other villages share the same name. Sometimes this seems to be related to phenomena of population displacement caused by forced deportation or spontaneous migrations. The prosecution of the ethnographical research will certainly throw new light on these interesting issues.

Documentation of archaeological sites includes their exact positioning using GPS devices (georeferencing), the delimitation of their extent and surface, a high-resolution photographic documentation and detailed indexing and cataloguing. Different types of archaeological material sampling are carried out on each site. Regarding the ceramic material diagnostic fragments are collected from the entire surface of the site while in order to obtain an overall picture of the site chronology and in some limited sample areas (typically measuring $5 \times 5 \mathrm{~m}$ ) the collection includes all potsherds found (Cereti et al, 2014). All finds are catalogued in laboratories set up in the city of Sulaimaniyah, in the temporary locations of the MAIKI or in the stores of the Archaeological Museum. The careful study of the artefacts is a core mission of MAIKI, not only because it helps to fix the chronology and to better understand the typology of the archaeological sites, but they are a fundamental resource for compiling the map of local productions and imports over time. Meanwhile, recent collaboration between Sapienza University of Rome (LANDA, the Laboratory of Non-Destructive Analysis and Archaeometry in $f$ the Department of Basic and 
Applied Sciences for Engineering) and University of Roma Tre (Department of Sciences, Section of Geological Sciences) has given rise to a new project on the cataloguing and detailed analysis of the ceramic fabrics found in the area.

J.B.

\section{Preliminary Results}

Of course, the project's collected and studied data are still incomplete but the first preliminary results lead us to be optimistic about the eventual outcome. Preliminary analysis suggests that the majority of the sites reported in the Iraqi Atlas (Atlas of the archaeological sites, 1975: 99) are still in a good state of preservation, despite the traumatic events suffered by the area. Nevertheless, some cases of destruction have been documented, possibly due to war, village constructions or robbery. The new archaeological documentation has greatly improved our knowledge of the area and we are now able to propose a preliminary classification of the visited sites as well as a rough chronology. In addition, the intensive survey, although very limited, led to the identification of many new sites. To date, 95 villages, 30 archaeological sites, 21 modern or contemporary cemeteries and seventeen places of religious significance have been identified and geo-referenced using GPS.

The data provide evidence for this area being frequented and inhabited at least since the Uruk period (fourth millennium BC), as indicated by Bevelled Rim Bowl fragments from two sites. Moreover, in-depth analysis of the archaeological material has identified Hellenistic phases at four sites, Sasanian at two sites, proto-Islamic leighth centuryl and Abbasid phases (eighth-thirteenth centuries) at five sites and finally, Ottoman phases (sixteenth-eighteenth century) at many sites (currently seven). While these data, albeit incomplete, confirm beyond any reasonable doubt that the area has been inhabited for a very long timespan, it is still too early to formulate any reliable hypothesis on the human activity in this region. The fragmentary nature of the data makes it premature to argue e silentio about the lack of key materials for some crucial historical periods, such as the Achaemenid Age.

L.C.

\section{Beyond Archaeology}

Since December 2014 MAIKI activities in the area have been flanked by ethnographic research focusing on the local religious heritage and practices. Here only some preliminary results on the most recent settlement dynamics of the area can be given to complement the outline above.

The territory investigated so far is currently inhabited by the Jaf, Zangana, Pizhdar and Jalali, formerly nomadic tribes la term commonly used by the local population and well attested in the literature; for an analysis of the term in a Kurdish contest see Van Bruissen, 2002), and by sedentary non-tribal peasant, guran, and the shakhly dynasties of the Barzanji. Consistent with the existing literature, each tribe has clearly defined territorial rights (Van Bruinessen, 1992: 53-56) hence the homogeneous population of the majority of the villages, with the sole exceptions of the shaykh centres, where different tribal affiliations coexist. The villages comprise between three and 30 households and have homogeneous subsistence systems based on food crops and pastoralism. The vast majority of the inhabitants practice transhumance, relocating their livestock, mainly sheep and goats, to the heights of the Sagrma or the nearby plain of Sharazur, east of these mountains.

The Jaf, the vast majority of the local population, according to our informants, were once long-range nomads, seasonally migrating to and from between Iran until the beginning of twentieth century when reinforced controls on the Iranian border finally forced them to settle (C etinsaya, 2006: 72-85). Former seasonal camps were gradually replaced by permanent settlements, built in mud bricks, ultimately leading in the 1930s to the current shape and placement of all the villages. The Zangana, Pizhdar and Jalali tribes were also nomadic within living memory in the Iraqi inland 
but it is likely that they followed similar settlement dynamics and chronologies.

The guran, traditionally settled peasants (Van Bruissen, 1992: 109-15) are connected to the shaykh centre of Krpchna, a village close to the pass of Hanaray (see above); in their recounts there is no memory of movements or migrations. The villages predominantly populated by shaykhs are born and developed around takya, centres dedicated to Sufi meetings and prayer, and their chronology can be traced in the religious heritage of the area. Concerning Krpchna, the informants report that the village was founded by Shaykh Abdul Karim (1824-1902) who established here the Kasnazaniyya, a branch of the Qadiriyya Sufi brotherhood (Avaz, 2003). However, according to other sources (Kasnazaniyya, 2015), this centre insists on an earlier settlement of which no other information is known. Similarly the dating of mosques and tombs of influential figures located in other shaykh villages suggest that these villages predate the end of nineteenth century. Their pre-existence to the progressive settlement of the nomadic tribes and their role as religious gathering place may partly explain the co-residence of different tribes. Other religious focuses are the village of Hashazeni, site of another Sufi centre that can be considered a competitor of Krpchna and Sangaw, which recently stands as an orthodox counterpoint to the Sufism, traditionally widely attested in the area. It is worth noting that Sangaw, in size and administrative role, is currently the only urban centre of the territory.

In 1988 the area was dramatically affected by the “Al-Anfal” campaign, conducted by Saddam Hussein against the Kurdish population (Black, 1993). There are reports of the complete destruction of villages and the forced displacement of their entire population to nearby urban centres. In the early 1990s, however, almost all the villages were rebuilt although according to local sources only $60 \%$ of the previous inhabitants returned. Over the following decades, the lack of infrastructure and services and persistent political instability triggered further migration to urban centres. If the data provided are correct, in the last two decades, the population of the area has been reduced by a further $40 \%$ thus making uncertain the future of the current rural settlements of the area. C.I.

\section{Conclusion}

More than once in this provisional outline of MAIKI activities in the area of Paikuli we called upon the incompleteness of the record, highlighting the logistical and methodological problems, for not offering an overall interpretation of the available data. It is certainly too soon to propose a reliable reconstruction for the area of the history of man and his interaction with nature, the action that shapes the landscape. Nevertheless we can draw a line under a few considerations.

The landscape of this area is mostly the result, today as in antiquity, of natural action. Human intervention, over the centuries, has been limited to a few measures aimed to better adapt the naturally favourable situations: opening of roads and passages, use of water and other resources. although it should be noted that recently a more intensive and possibly disproportionate use of natural resources is documented. As a consequence, the sole study of the archaeological data is not sufficient to coherently reconstruct the human history of this area. Indeed, its contextualisation in the environment and the analysis of the resulting landscape over time can undeniably offer a better basis for interpretation. Thus, the identification of natural resources (morphological, geological, hydrographicall and the ethnographic documentation of rapidly changing cultural phenomena can help us bridge the inevitable gap in the archaeological documentation.

This multidisciplinary approach could be particularly fruitful for archaeologically unknown contexts located in politically unstable areas. It is plain, and our most recent experience shows it clearly, that in these regions it is very difficult to plan and carry out long-term projects and every field campaign might well be the last for a long time. Therefore, alongside specific research 
priorities, it is necessary to be prepared to rapidly and accurately record and document sites, of any chronological period, or artefacts, behaviours and practices, which might suddenly be at immediate risk.

Finally, we are aware that our investigation of the past could have important consequences in the present day life of these regions. The affirmation and modelling of Kurdish identity, exactly because it has been for long time under threat, is an extremely active process. Archaeologists have only recently started to play an important role. Archaeology is sometimes called into question to establish and defend land claims, to search in the past the roots of the present. It is significant, that the citadel of Erbil, recently declared a UNESCO World Heritage Site, is usually called by the Kurdish governance the 'oldest continuously inhabited settlement in the world' (Kurdistan, 2015).

In considering the deep impact of the archaeological discourse on present socio-political life we must take into account the wider notion of Cultural Heritage, whose crucial role in local narratives is today abruptly evident in the actions of "Daesh". Since 2014 this group has publicly destroyed mausolea, mosques and churches in the Mosul area, up to the recent infamous devastations of the sites of Niniveh, Hatra and Palmira. This is a clear and violent attempt to confront and challenge these cultural identities, which have been growing from roots in the glorious past of the region.

J.B., L.C., C.I.

\section{References}

Atlas of the archaeological sites in Iraq, 1975: General Directorate of Antiquities, Baghdad.

Avaz K, 2003: Le suofisme au Kurdistan irakien. Etude sur le groupement du Kesnizaniya, unpublished thesis, Université de Sorbonne Paris IV.

Black G, 1993: Genocide in Iraq. The Anfal campaign against the Kurds, Human Rights Watch, New York.

Cereti CG \& R Giunta 2012: Preservation of the cultur- al heritage of the Kurdistan region in Iraq. Italian Cooperation Project in Iraqi Kurdistan (2009-2010), Bologna 2012, IsIAO, Rome.

Cereti CG \& G Terribili 2012: The Paikuli Monument, in Alram M \& Gyselen R (ed.), Sylloge Nummorum Sasanidarum, vol 2. Ohrmazd I.-Ohrmazd II: 74-87. Verlag der Österreichischen Akademie der Wissenschaften, Vienna.

Cereti CG \& G Terribili 2014: The Middle Persian and Parthian Inscriptions on the Paikuli Tower. New Blocks and Preliminary Studies, Iranica Antiqua, 49: 347-412.

Cereti CG, G Terribili \& A Tilia (in press): Pāikūlī in its Geographical Context, in Proceedings of the 7th European Conference of Iranian Studies (Cracow 7-10 September 2011).

Cereti CG, L Colliva, J Bogdani, A Fusaro, M Galuppi, C Insom, RR Kamal, G Labisi \& S Mancini 2014: MAIKI, Missione Archeologica Italiana nel Kurdistan Iracheno: la carta archeologica dell'area di Paikuli, obiettivi e metodologie, Vicino Oriente, 18, 25-38.

Çetinsaya G, 2006: Ottoman administration of Iraq, 18901908, Routledge, London/New York.

Guest E, 1966: The vegetation of Iraq and adjacent regions, in Guest E, Flora of Iraq, vol 1, Introduction to the flora: an account of the geology, soils, climate and ecology of Iraq with gazetteer, glossary and bibliography: 55-108. Ministry of agriculture of the Republic of Iraq, Baghdad.

Herzfeld E, 1924: Paikuli. Monument and Inscription of the Early History of the Sassanian Empire, Berlin, viewed 20 August 2015, http://digital.library.stonybrook.edu/cdm/ref/collection/amar/id/159646

Huyse P, 1999: Die dreisprachige Inschrift Šābuhrs 1. an der Ka 'ba-i Zardušt (ŠKZ), P. Lund, Humphries \& Co, London.

Kasnazaniyya official web site, 2015: viewed August 20, 2015, http://www.kasnazan.com/

Kurdistan Regional Government Representation in Italy, 2015: viewed August 20, 2015, http://italy.krg.org/ about_kurdistan.html

Sissakian VK, 2010: Neotectonic Movements in Darbandi Bazian Area, Southwest of Sulaimaniyah City, NE Iraq, Iraqi Bulletin of Geology and Mining, 6(2): 57-69. Stansfield GRV, 2003: Iraqi Kurdistan. Political Development and emergent democracy, Routledge London/ 
New York

Ur JA, 2003: CORONA Satellite Photography and Ancient Road Networks: A Northern Mesopotamian Case Study, Antiquity, 77(295): 102-15, viewed August 20, 2015, http://dash.harvard.edu/handle/1/4269008 Ur JA, 2013: CORONA Satellite Imagery and Ancient Near Eastern Landscapes, in Comer DC \& Harrower MJ (ed.), Mapping Archaeological Landscapes from Space: 31-41. Springer, New York.

Van Bruissen M, 1992: Agha, Shaikh and the State. The Social and political Structures of Kurdistan, Zed Books, London/Atlantic Highlands, NJ.

Van Bruissen M, 2002: Kurds, states and tribes, in 'Abd al-Jabbār F \& Dawod H, Tribes and power: nationalism and ethnicity in the Middle East: 165-83. Saqi, London. 
